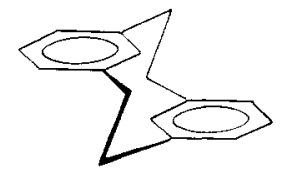

1
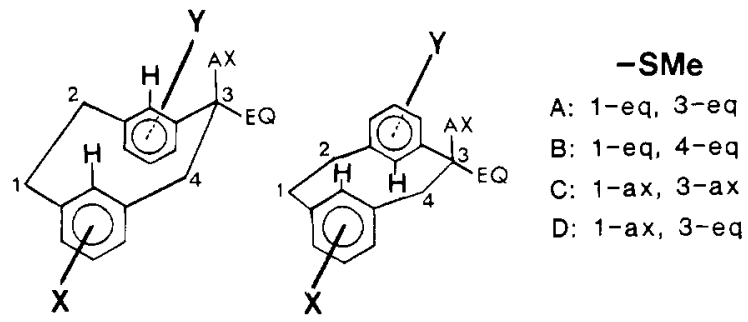

$X \quad Y$

3: Absent Absent

6: $\mathrm{Cr}(\mathrm{CO})_{3}$ Absent

$$
\begin{array}{cc}
\text { X } & Y \\
\text { 4: Absent } & \text { Absent } \\
\text { 7: } \mathrm{Cr}(\mathrm{CO})_{3} & \mathrm{Absent}
\end{array}
$$$$
\text { 9: } \mathrm{Cr}(\mathrm{CO})_{3} \mathrm{Cr}(\mathrm{CO})_{3} \text { 10: } \mathrm{Cr}(\mathrm{CO})_{3} \mathrm{Cr}(\mathrm{CO})_{3}
$$

However, subsequent removal of such substituents after expulsion of sulfur and ring contraction to give the parent cyclophanes has not yet proved possible. ${ }^{6,7}$ We therefore thought that use of an (arene)chromium tricarbonyl derivative would solve this problem, in that the strong electron-withdrawing nature of the $\mathrm{Cr}(\mathrm{CO})_{3}$ fragment would stabilize $s y n$-cyclophanes by charge transfer across the cofacial decks ${ }^{6}$ and yet would be easily removed ${ }^{8}$ later.

No (arene)chromium tricarbonyl derivatives of simple thiacyclophanes are known; ${ }^{9}$ however, reflux of syn-2,11-dithia[3.3] metacyclophane with $\mathrm{Cr}(\mathrm{CO})_{6}$ in $n-\mathrm{Bu}_{2} \mathrm{O}$ readily gave $70 \%$ of syn-5. The internal hydrogens of 5 appeared at $\delta 7.23$ and 4.83 clearly confirming the syn configuration.

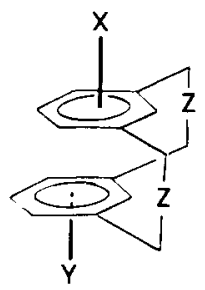

$$
\begin{aligned}
& \text { 5: } X=C r(C O)_{3}, Y=A b \text { sent, } Z=S \\
& \text { 8: } X=Y=C r(C O)_{3}, Z=S \\
& \text { 11: } X=\mathrm{Cr}(\mathrm{CO})_{3}, Y=Z=A \text { bsent } \\
& \text { 12: } X=Y=C r(C O)_{3}, Z=A b \text { sent }
\end{aligned}
$$

Methylation of 5 with $\left(\mathrm{CH}_{3} \mathrm{O}\right)_{2} \mathrm{CHBF}_{4}$ followed by Stevens rearrangement ${ }^{5}$ gave $(70 \%)$ the syn-[2.2] metacyclophane $6 \mathrm{D}$, as yellow crystals, $\mathrm{mp} 120-121^{\circ} \mathrm{C}$. The syn configuration of $6 \mathrm{D}$ was confirmed by (i) the internal hydrogen signals at $\delta 6.93$ and 5.51 , (ii) an X-ray crystallographic structure determination, ${ }^{11}$ and

(7) Mitchell, R. H.; Williams, R. V., unpublished results.

(8) Nicholls, B.; whiting, M. C. J. Chem. Soc. 1959, 551-556. Card, R. J.; Trahanovsky, W. S. J. Org. Chem. 1980, 45, 2560-2566.

(9) Balbach, B. K.; Koray, A. R.; Okur, H.; Wülknitz, P.; Ziegler, M. L. J. Organomet. Chem. 1981, 212, 77-94.

(10) Note, however, we find that whereas syn-9,18-dimethyl-2,11-dithia[3.3] metacyclophane reacts readily with $\mathrm{Cr}(\mathrm{CO})_{6}$ to give $(70 \%)$ the $\mathrm{Cr}(\mathrm{CO})_{3}$ adduct ( $\mathrm{mp} 202{ }^{\circ} \mathrm{C} \mathrm{dec}$, the anti isomer is resistant and requires the more reactive $\mathrm{Cr}(\mathrm{CO})_{3}\left(\mathrm{CH}_{3} \mathrm{CN}\right)_{3}$ and then only gives $20 \%$ of product mp $220^{\circ} \mathrm{C}$ dec.

(11) The crystal structure was triclinic, space group $P \overline{1}$ (No. 2), with $a=$ $10.087(6) \AA, b=11.276(7) \AA, c=9.739$ (5) $\AA, \alpha=112.42(4)^{\circ}, \beta=98.21$ (4) ${ }^{\circ}, \gamma=82.91(4)^{\circ}, D_{\text {meas }}=1.422 \mathrm{~g} / \mathrm{cm}^{-3}, D_{\text {calcd }}=1.434 \mathrm{~g} / \mathrm{cm}^{-3}, Z=2$ molecules per cell. Measurements were made on a Picker 4-circle diffractometer, automated with a PDP11 computer. The structure was solved by direct methods and refined by least squares to $R=0.0391$ and $R_{w}=0.0517$ for 1599 observations $[I>2 \sigma(I)]$ and 302 parameters. the angle between the aromatic ring mean planes is $28.8^{\circ}$. the structural details will be published elsewhere. (iii) isomerization $\left(80^{\circ} \mathrm{C}, 1 \mathrm{~h}\right)$ to the anti-cyclophane in which both $\mathrm{SMe}$ groups are now axial, $7 \mathrm{C}, \mathrm{mp} 128^{\circ} \mathrm{C}$, internal hydrogens at $\delta 5.91$ and 3.42. This was further confirmed by removal of the chromium from $7 \mathrm{C}$ with $\mathrm{Ce}^{\mathrm{IV}}$ in $\mathrm{CH}_{3} \mathrm{CN}$ to give $4 \mathrm{C} .{ }^{5 \mathrm{~b}}$ Treatment of $4 \mathrm{C}$ with $\mathrm{Cr}(\mathrm{CO})_{6}$ in $n-\mathrm{Bu}_{2} \mathrm{O}$ regenerated $7 \mathrm{C}$, confirming its structure. Treatment of $6 \mathrm{D}$ with $\mathrm{Ce}^{\mathrm{IV}}$ in $\mathrm{CH}_{3} \mathrm{CN}$ at $-35^{\circ} \mathrm{C}$, followed by isolation and chromatography of the product also at $-35^{\circ} \mathrm{C}$, gave the first syn-[2.2] metacyclophane, 3D, in which the internal hydrogens were at $\delta 7.04$ and 6.75 and the other aromatic hydrogens were shielded by the cofacial rings at $\delta$ 7.00-6.30. If a solution of $3 \mathrm{D}$ were allowed to warm above $0{ }^{\circ} \mathrm{C}$, isomerization to the anti-cyclophane $\mathbf{4 A}$ occurred.

When $6 \mathrm{D}$ isomerizes to $7 \mathrm{C}$, the $3(\mathrm{e})-\mathrm{SMe} \rightarrow 3(\mathrm{a})-\mathrm{SMe}$, i.e., the noncomplexed ring flips, whereas when $3 \mathrm{D}$ isomerizes to $\mathbf{4 A}$, the $1(\mathrm{a})-\mathrm{SMe} \rightarrow 1(\mathrm{e})-\mathrm{SMe}$, indicating that the opposite ring has flipped. Attempted removal of the SMe groups from either 3D or $6 \mathrm{D}$ by $\mathrm{Li} / \mathrm{NH}_{3}$ reduction at $-40^{\circ} \mathrm{C}$ unfortunately only gave complexed and uncomplexed anti-cyclophane 1, because ring flip of the uncomplexed ring probably occurred during the reduction, along with some decomplexation. We thus, using excess $\mathrm{Cr}(\mathrm{CO})_{6}$, prepared in $62 \%$ yield the bis complex 8, mp 199-201 ${ }^{\circ} \mathrm{C}$, which would not be expected to ring flip readily. Stevens rearrangement gave $9 \mathrm{D}$ in $40 \%$ yield, which on reduction with $\mathrm{Li} / \mathrm{NH}_{3}$ at -40 ${ }^{\circ} \mathrm{C}$ yielded a mixture of $\mathbf{1 1}$ and 12, the first derivatives of unsubstituted 2 known. 11 isomerizes on heating by flipping the uncomplexed ring to give the known complexed anti-cyclophane. ${ }^{12}$ The ${ }^{1} \mathrm{H}$ NMR spectrum of $\mathbf{1 2}$ shows the internal hydrogens at $\delta 5.09$ and the external hydrogens at $\delta 5.10$ and 4.75 , with bridge protons at $\delta 2.98-2.79$, which leaves no doubt as to its structural assignment. Removal of the complexing $\mathrm{Cr}(\mathrm{CO})_{3}$ moiety with $m$-chloroperbenzoic acid or $\mathrm{Ce}^{\mathrm{IV}}$ at $-45^{\circ} \mathrm{C}$ in $\mathrm{CH}_{3} \mathrm{CN}$ yielded syn-[2.2] metacyclophane (2), which rapidly isomerized to 1 above $0{ }^{\circ} \mathrm{C}$. The ${ }^{1} \mathrm{H}$ NMR spectrum of 2 at $-40^{\circ} \mathrm{C}$ showed the internal hydrogens at $\delta 6.58$, the external hydrogens at $\delta 6.36$ and 6.60 , and the bridge hydrogens at $\delta 3.14$ and 2.85 . In due course we hope to obtain a solid sample of $\mathbf{2}$ and study the kinetics of its isomerization of 1 . Thus at last some 25 years after the synthesis of $\mathbf{1}$ was confirmed, a synthesis of $\mathbf{2}$ has proved possible using a $\mathrm{Cr}(\mathrm{CO})_{3}$ moiety to control cyclophane stereochemistry.

(12) Langer, E.; Lehner, H. Tetrahedron 1973, 29, 375-383.

\section{Characterization of 10-Hydroxybacteriochlorophyll a by ENDOR and TRIPLE Resonance Spectroscopy}

\author{
W. Lubitz,${ }^{* \dagger}$ F. Lendzian,${ }^{\ddagger}$ and H. Scheer ${ }^{\S}$
}

Institut für Organische Chemie and Institut für Molekülphysik, Freie Universität Berlin 1000 Berlin 33, West Germany

Botanisches Institut der Universität München 8000 München 19. West Germany

Received October 22, 1984

Although the bacteriochlorophyll $a$ (BChl $a$, see Figure 1) radical cation plays a central role as a primary photoproduct in bacterial photosynthesis, ${ }^{1-4}$ a detailed map of its spin density distribution was difficult to obtain for the following reasons: (i) the parent compound $\mathrm{BChl} a$ was unstable and was frequently

${ }^{\dagger}$ Institut für Organische Chemie.

¥Institut für Molekülphysik.

Botanisches Institut.

(1) Hoff, A. J. in "Light Reaction Path of Photosynthesis"; Fong, F. K., Ed.; Springer: Berlin, 1982; pp 80-151, 322-326. Hoff, A J. Biophys. Struct. Mech. 1982, 8, 107-150.

(2) Parson, W. W. Ann. Rev. Biophys. Bioeng. 1982, 11, 57-80.

(3) Norris, J. R.; Katz, J. J. In "The Photosynthetic Bacteria"; Clayton, R. K., Sistrom, W. S., Eds.; Plenum: New York, 1978; pp 397-418.

(4) Feher, G.; Hoff, A. J.; Isaacson, R. A.; Ackerson, L. C. Ann. N. Y. Acad. Sci. 1975, 244, 239-259. 


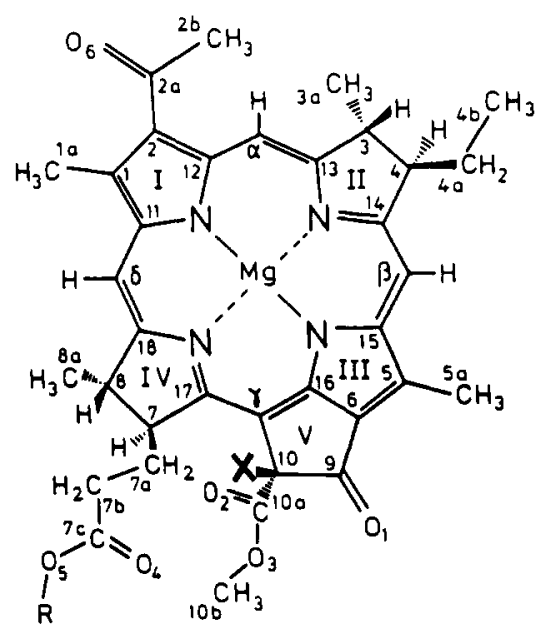

Figure 1. Molecular structure of bacteriochlorophyll $a(\mathrm{X}=\mathrm{H})$ and 10-hydroxybacteriochlorophyll $a(\mathrm{X}=\mathrm{OH}$, for steric arrangement see ref 15). The side chain $\mathrm{R}$ is $\mathrm{C}_{20} \mathrm{H}_{33}$ (geranylgeranyl) in $R s$. rubrum.

converted to alteration products, in particular in the light, in solution, and/or in the presence of oxidants. ${ }^{5}$ (ii) EPR, ${ }^{6}$ NMR, ${ }^{7}$ and solid-state ENDOR ${ }^{1,3,4,8}$ techniques employed in the past suffered from a lack of resolution or sensitivity. With the advent of advanced ENDOR methods ${ }^{9,10}$ the investigation of complex biomolecules like the BChl $a^{+}$. became possible in liquid solution where all hyperfine coupled nuclei give rise to relatively sharp resonance lines due to the absence of anisotropic broadening. Electron-nuclear-nuclear TRIPLE resonance ${ }^{9,10}$ increases the sensivity and resolution of the ENDOR spectra (Special TRIPLE) and allows (General TRIPLE) the determination of the relative signs of the hyperfine coupling constants (hfc's).

There have been three reports of ENDOR in solution on $\mathrm{BChl}$ $a^{+}$. in the literature ${ }^{11-13}$ that gave conflicting results. In the course of our studies of this species ${ }^{13,14}$ we frequently observed paramagnetic byproducts in the ENDOR spectra. It is known that chlorophylls and bacteriochlorophylls undergo allomerization in alcoholic solutions to form products with modifications in the isocyclic ring V. ${ }^{5}$ 10-Hydroxybacteriochlorophyll $a$ (10-OHBChl $a$ ) is considered to be the main BChl $a$ allomer. It is virtually indistinguishable from $\mathrm{BChl} a$ by its optical spectrum but recently has been characterized through ${ }^{1} \mathrm{H}$ NMR and MS spectroscopy. ${ }^{15}$ In this paper we present a ${ }^{1} \mathrm{H}$ ENDOR study of the cation radical of $10-\mathrm{OHBChl} a$ and compare it to that of $\mathrm{BChl} a$. On the basis of these results the discrepancy between previously published hfc's of $\mathrm{BChl} a^{+} .11,12$ is solved, and it is demonstrated that ENDOR can serve as a sensitive tool to detect even small structural changes in complex bioorganic radicals.

BChl $a$ was isolated from Rs. rubrum G-9 according to ref 16 . This method yielded varying amounts of $10-\mathrm{OHBChl} a^{15}$ that were

(5) Svec, W. A. In "The Porphyrins"; Dolphin, D., Ed.; Academic: New York, 1979; Vol. V, pp 342-399.

(6) Fajer, J.; Davis, M. S. In "The Porphyrins"; Dolphin, D., Ed.; Academic: New York, 1979; Vol. IV, pp 198-256.

(7) Waterton, J. C.; Sanders, J. K. M. J. Am. Chem. Soc. 1978, 100, 4044-4049.

(8) Norris, J. R.; Scheer, H,; Katz, J. J. In "The Porphyrins"; Dolphin, D., Ed.; Academic: New York, 1979; Vol. IV, pp 159-195. Norris, J. R.; Scheer, H.; Katz, J. J. Ann. N. Y. Acad. Sci. 1975, 244, 260-280.

(9) Möbius, K.; Plato, M.; Lubitz, W. Phys. Rep. 1982, 87, 171-208. (10) Kurreck, H.; Kirste, B.; Lubitz, W. Angew. Chem., Int. Ed. Engl. 1984, 23, 173-194.

(11) Borg, D. C.; Forman, A.; Fajer, J. J. Am. Chem. Soc. 1976, 98, $6889-6893$

(12) Hoff, A. J.; Möbius, K. Proc. Natl. Acad. Sci. U.S.A. 1978, 75 , 2296-2300

(13) Lubitz, W.; Lendzian, F.; Scheer, H.; Gottstein, J.; Plato, M.; Möbius, K. Proc. Natl. Acad. Sci. U.S.A. 1984, 81, 1401-1405.

(14) Lubitz, W.; Lendzian, F.; Plato, M.; Möbius, K.; Scheer, H., manuscript in preparation.

(15) Brereton, R. G.; Rajananda, V.; Blake, T. J.; Sanders, J. K. M.; Williams, D. H. Tetrahedron Lett. 1980, 21, 1671-1674.

(16) Katz, J. J.; Strain, H. H.; Harkness, A. L.; Studier, M. H.; Svec, W. A.; Janson, T. R.; Cope, B. T. J. Am. Chem. Soc. 1972, 94, 7938-7939.

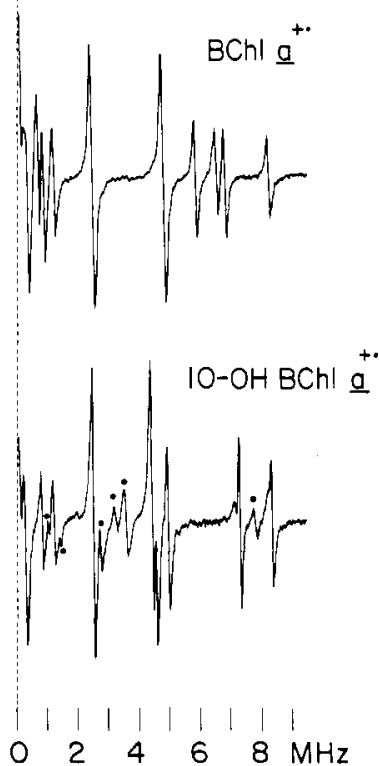

Figure 2. Special TRIPLE resonance spectra from BChl $a^{+}$. (top) and 10-OHBChl $a^{+}$. (bottom); for hfc's see Table I. The dots in the lower trace indicate lines assigned to a paramagnetic decomposition product of 10-OHBChl $a$ (see text). Experimental conditions: $255 \mathrm{~K}$, $\mathrm{rf}$ power $2 \times 100 \mathrm{~W}$, microwave power $40 \mathrm{~mW}, 10 \mathrm{kHz} F M$ modulation of if field, depth $100 \mathrm{kHz}, 4$ scans (bottom), 1 scan (top), 800 s each, time constant $1.25 \mathrm{~s}$.

Table I. ${ }^{1} \mathrm{H}$ Hfc's (MHz) of BChl $a$ and 10-OHBChl $a$ Cation Radicals

$\begin{array}{rrrrrl}\hline & \multicolumn{3}{c}{\text { BChl } a^{+} .} & \text {10-OHBChl } a^{+} . \\$\cline { 2 - 4 } & $\left.a & b & c & a & \text { assignments }^{d} \\ \hline 1 & -0.15 & & -0.16 & -0.22 & 2 \mathrm{~b} \\ 2 & -0.50 & & -0.57 & -0.57 & 3 \mathrm{a}, 4 \mathrm{a}, 7 \mathrm{a}, 8 \mathrm{a} \\ 3 & +1.30 & 1.52 & +1.59 & +1.65 & \alpha, \beta, \delta \\ 4 & +2.30 & & +2.42 & +2.46 & \\ 5 & -1.65 & & & & 10 \\ 6 & +4.85 & 4.78 & +5.06 & +5.05 & 1 \mathrm{a} \\ 7 & +9.50 & 9.44 & +9.04 & +8.89 & 5 \mathrm{a} \\ 8 & +11.61 & 11.48 & e & +9.25 \\ 9 & +13.00 & 12.92 & +9.9 & +10.01 \\ 10 & +13.59 & 13.48 & +14.5^{f} & +14.66 \\ 11 & +16.43 & 16.38 & +16.7 & +16.77\end{array}\right\}$

${ }^{a}$ This work $(255 \mathrm{~K})$, error $\pm 20 \mathrm{kHz} .{ }^{b}$ From ref $11(273 \mathrm{~K}) .{ }^{c}$ From ref $12(212 \mathrm{~K}) .{ }^{d}$ For numbering scheme, see Figure 1; assignments based on partial deuteration ${ }^{20}$ and comparison with $\mathrm{NMR}^{7}$ and MO calculations ${ }^{14}$ (see also ref 18,19 ). ${ }^{\circ} \mathrm{A}$ hfc of $9.2 \mathrm{MHz}$ can be obtained from the ENDOR spectrum in ref 12 (Figure 2B). ${ }^{f}$ The authors have observed an additional shoulder on this line yielding a $\mathrm{hfc}$ of 14.0 $\mathrm{MHz}$.

separated from Bchl $a$ by chromatography on powdered sugar ${ }^{5}$ or DEAE cellulose. ${ }^{17}$ The ${ }^{1} \mathrm{H}$ NMR spectrum was identical with that given in ref 15 . The cation radicals of BChl $a$ and 10OHBChl $a\left(\sim 3 \times 10^{-4} \mathrm{M}\right)$ were generated by iodine oxidation (5 $\mathrm{M}$ excess) in a mixture of dichloromethane and methanol (6:1, by volume) by using high-vacuum techniques and thoroughly purified and outgassed solvents. ENDOR and TRIPLE resonance measurements were performed on a self-built spectrometer that has been described previously. ${ }^{9}$

In Figure 2, top, the Special TRIPLE resonance spectrum of $\mathrm{BChl} a^{+}$. is depicted which is essentially free of byproducts. Eleven

(17) Omata, T.; Murata, N. Plant Cell Physiol. 1983, 24, 1093-1100.

(18) Petke, J. D.; Maggiora, G. M.; Shipman, L. L.; Christoffersen, R. E. Photochem. Photobiol, 1980, 31, 243-257.

(19) Davis, M. S.; Forman, A.; Hanson, L. K.; Thornber, J. P.; Fajer, J. J. Phys. Chem. 1979, 83, 3325-3332.

(20) Partially deuterated BChl $a$ and 10-OHBChl $a$ were obtained by growing Rs. rubrum G-9 in D,O ( $\sim 99 \%)$ with $2,3-\mathrm{H}_{4}$-succinate as sole carbon source or vice versa with deuterated succinate in $\mathrm{H}_{2} \mathrm{O}$. For details and isotopic composition see ref 13 and 14 . 
${ }^{1} \mathrm{H}$ hfc's can directly be deduced. In Figure 2, bottom, the spectrum of $10-\mathrm{OHBChl} \mathrm{a}^{+}$. is shown. All hfc's including their signs from General TRIPLE were assigned to molecular positions (see Table I).

When the proton in position 10 was substituted against hydroxyl, changes of the ${ }^{1} \mathrm{H}$ hfc's in the vicinity of ring $\mathrm{V}$ were expected. As is obvious from Table I, a predominant shift occurred for the methyl proton hfe 7 (ring III) and for the $\beta$-proton couplings 8 and 9 . The latter are tentatively assigned to ring IV, rather than to ring II, due to the anticipated change in the steric interaction between the substitutents at $C_{10}$ and $C_{7}$ (Figure 1). In the range of the small couplings $1-5$ (Table I) the most prominent feature is the absence of the ${ }^{1} \mathrm{H}$ hfc 5 , that was assigned to position 10 in $\mathrm{BChl} a^{+}$. The ${ }^{1} \mathrm{H}$ hfc of the hydroxyl group, a $\gamma$-coupling, is expected to be close to zero.

Our ${ }^{1} \mathrm{H}$ hfc's 6-11 from the BChl $a^{+}$. are in excellent agreement with those reported in ref 11 , the smaller ones have not been resolved in this paper (Table I). The data given in ref 12 for $\mathrm{BChl}$ $a^{+}$. are, however, very close to our values of the 10-OHBChl $a^{+}$. (see Table I). It is therefore proposed that the latter authors have used 10-OHBChl $a$ that, presumably, was formed during a prolonged isolation and purification procedure of the bacteriochlorophyll in alcoholic solvents under aerobic conditions. ${ }^{21}$

The dots in the spectrum of Figure 2, bottom, indicate lines assigned to a paramagnetic byproduct ${ }^{26}$ with a similar $g$ factor. The resonances belonging to this species can be identified by General TRIPLE resonance, ${ }^{10}$ a method that is based on the fact that ENDOR lines of a second radical in the sample show no "TRIPLE effect" when pumping transitions of the first radical. Since the starting material was free of byproducts this species must have been formed from 10-OHBChl $a$ in the sample tube. The amount of the byproduct, which has not yet been identified, depends upon experimental conditions (reaction time, temperature, solvents). Pheophytinization or oxidation ${ }^{5}$ to 10 -hydroxy-2-devinyl-2-acetylchlorophyll $a$ is unlikely from a comparison with the ENDOR data of such samples. ${ }^{27}$ Due to the quite large changes in particular of the methyl hfc's in rings I and III $^{26}$ a species with an opened ring $V$ seems to be most probable. ${ }^{28}$ An alternative explanation is the formation of a 10 -methoxylactone, which is another major byproduct of chlorophyll allomerization. ${ }^{5}$

Acknowledgment. This work was supported by Deutsche Forschungsgemeinschaft, Sfb 161 (W.L., F.L.) and 143 (H.S.).

Registry No. 10-OH BChl $a^{+\cdot}$, 96095-15-7; BChl $a^{+}$, 36643-16-0.

(21) The formation of 10-OHBChl $a$, sometimes even as the major bacteriochlorin, in BChl $a$ isolation procuedures has been mentioned. ${ }^{, 15}, 22$ The use of alcoholic solvents like methanol for the extraction and chromatography of BChl $a$ is superior to other methods because of the stabilization of the species by sixfold ligation of the central $\mathrm{Mg}$ that prevents the formation of certain byproducts. ${ }^{22}$ Allomerization can be reduced to a minimum by working in dim green light with ice-cold oxygen-free solvents and by avoiding a prolonged contact. ${ }^{22,23}$ Methanol is also an important cosolvent for the BChl a cation radical ${ }^{14}$ It should be noted that other bacteriochlorophylls, e.g. $\mathrm{BChl} b$, are even more labile than $\mathrm{BChl} a$ and readily yield pigments of the chlorophyll spectral type. ${ }^{25}$

(22) Brereton, R. G.; Sanders, J. K. M. J. Chem. Soc., Perkin Trans. 1 1983, 423-430, 431-434.

(23) Lubitz, W.; Isaacson, R. A.; Abresch, E. C.; Feher, G. Proc. Natl. Acad. Sci. U.S.A. 1984, 81, 7792-7796.

(24) Reference deleted in proof.

(25) Steiner, R.; Cmiel, E.; Scheer, H. Z. Naturforsch., C 1983, 38C, $748-752$.

(26) The ' $\mathrm{H}$ hfc's $(\mathrm{MHz})$ of the paramagnetic byproduct are identified by ENDOR/General TRIPLE and tentatively assigned by partial deuteration: methines $(\alpha, \beta, \delta)+2.02,+2.80 ; \gamma \cdot$ protons $(3 a, 4 a, 7 a, 8 a)-0.60 ;$ methyls $(1 a, 5 a)$ $+5.52,+7.22 ; \beta$-protons $(3,4,7,8)+6.52,+15.62$ (shoulders are observed on other lines of the main spectrum yielding $10.5,14.3$, and $16.5 \mathrm{MHz}$, two of them could belong to the remaining $\beta$-protons)

(27) Lubitz, W., unpublished results.

(28) It is the presence (and geometry) of the isocyclic ring $\mathrm{V}$ in chlorophylls and bacteriochlorophylls that causes the asymmetry of the spin distribution in the respective radicals. This is most obvious from the ratio of the methyl hfe's in positions $5 \mathrm{a}$ and $1 \mathrm{a}$ : opening of ting $\mathrm{V}$ shifts this value close to one. ${ }^{29}$ For BChl $a^{+}, 10-$ OHBChl $a^{+}$, and the byproduct radical cation this ratio is $1.96,1.76$, and 1.31 , respectively.

(29) Scheer, H.; Katz, J. J.; Norris, J. R. J. Am. Chem. Soc. 1977, 99, $1372-1381$

\section{Simple Asymmetric Construction of Carbocyclic Framework. Direct Coupling of Dimenthyl Succinate with $1, \omega$-Dihalides}

Akihiro Misumi, Kiyoshi Iwanaga, Kyoji Furuta, and Hisashi Yamamoto*

\author{
Department of Applied Chemistry, Nagoya University \\ Chikusa, Nagoya 464, Japan \\ Received February 20, 1985
}

Efficient asymmetric carbocyclization processes may be one of the ultimate goals in organic synthesis. Among several potentially versatile methods, Diels-Alder reactions have been rather extensively studied, and in some cases high enantiomeric excesses were reported. ${ }^{1}$ We have been intrigued with the possibility of the developing 2 new asymmetric annulation protocols via direct coupling of the $1, \omega$-dihalides and the doubly charged succinate ions. $^{2}$ The present paper describes the initial results, which show the feasibility and some limitations of this approach.

The readily available (-)-dimenthyl succinate $(1,7.89 \mathrm{~g}, 20$ $\mathrm{mmol})^{3}$ in dry tetrahydrofuran $(20 \mathrm{~mL})$ was added dropwise at $-78^{\circ} \mathrm{C}$ to a solution of lithium $2,2,6,6$-tetramethylpiperidide ( 42 $\mathrm{mmol})$ in tetrahydrofuran $(60 \mathrm{~mL})$ under nitrogen. ${ }^{4}$ The resulting pale yellow solution was stirred there for $1 \mathrm{~h}$. The dianion thus obtained was treated with bromochloromethane $(0.65 \mathrm{~mL}, 10$ $\mathrm{mmol}$ ) dropwise at $-78^{\circ} \mathrm{C}$. After being stirred for $3 \mathrm{~h}$ at the same temperature, the reaction mixture was poured into ice-cold diluted hydrochloric acid, and the product was extracted several times with ether. The combined ether layers were washed with brine, dried over sodium sulfate, and concentrated in vacuo. The residue was subjected to column chromatography on silica gel using ether-hexane (1:19) as eluent to give (-)-dimenthyl cyclopropane-trans-1,2-dicarboxylate (2) as colorless crystals in 58\%

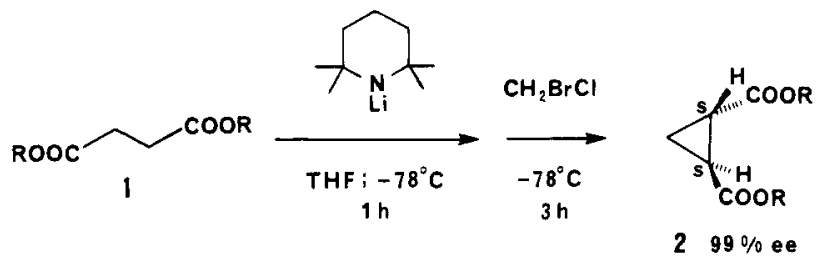

$\mathrm{R}=\ell$ - menthyl

yield $(2.34 \mathrm{~g})$ and in $99 \%$ de: $\mathrm{mp} 99-100^{\circ} \mathrm{C} \mathrm{(after} \mathrm{recrystal-}$ lization from methanol), $[\alpha]^{25.5}+17.8^{\circ}\left(c 1,0, \mathrm{CHCl}_{3}\right)$, identical in all respects with an authentic sample. ${ }^{5}$

(1) A recent review: Paquette, L. A. In "Asymmetric Synthesis"; Morrison, J. D., Ed.; Academic Press: New York, 1984; Vol. 3, Part B, Chapter 7.

(2) (a) Furuta, K.; Misumi, A.; Mori, A.; Yamamoto, H. Tetrahedron Lett. 1984, 25, 669. (b) Misumi, A.; Furuta, K.: Yamamoto, H. Ibid. 1984 25, 671. (c) Furuta, K.; Ikeda, N.; Yamamoto, H. Ibid., 1984, 25, 675 (3) (-)-Dimenthyl succinate: A mixture of succinic acid ( $23.6 \mathrm{~g}, 0.2 \mathrm{~mol})$, l-menthol $(62.5 \mathrm{~g}, 0.4 \mathrm{~mol})$, and concentrated hydrochloric acid $(0.6 \mathrm{~mL})$ was heated at $85-90^{\circ} \mathrm{C}$ (bath temperature) for $15 \mathrm{~h}$. Additional hydrochloric acid $(0.6 \mathrm{~mL})$ was added and the reaction mixture was heated for $15 \mathrm{~h}$ at the same temperature. The cooled organic layer was diluted with ether, washed with water, aqueous $\mathrm{NaHCO}_{3}$, and water, and concentrated in vacuo. The residue was recrystallized from methanol to give the diester 1 as colorless crystals $(33.2$ g. $42 \%): \operatorname{mp~} 65-66^{\circ} \mathrm{C},[\alpha]^{25} \mathrm{D}-88.7^{\circ}\left(\mathrm{c} 1.02, \mathrm{CHCl}_{3}\right.$ ).

(4) Dienolates derived from succinate esters; see: (a) Garratt, P. J.; Zahler. R. J. Am. Chem. Soc 1978, 100,7753 (b) Long N. R.; Rathke, M. W Synth. Commun. 1981, 11,687. (c) Bilyard, K. G.; Garratt, P. J.; Zahler R. Synthesis 1980, 389. (d) Bilyard, K. G.; Garratt, P. J.; Hunter, R.; Lete, E. J. Org. Chem. 1982, 47, 4731. (e) Girard, C.; Block, R. Tetrahedron Lett. 1982, 23, 3683. (f) Mahalanabis, K. K.; Mumtaz, M.; Snieckus, V. Ibid. 1982, 23, 3971, 3975 (1982). (g) Noire, P. D.; Franck, R. W. Ibid. 1982, 23 , 1031. (h) Pohmakotr, M.; Reutrakul, V.; Phongpradit, T.; Chansri, A. Chem. Lett. 1982, 687. (i) Wilkening, D.; Mundy, B. P. Synth. Commun. 1984, 13 , 227; (j) Tetrahedron Lett. 1984, 25, 4619.

(5) An authentic sample was prepared as follows: Trans isomer: Matsuda, H.; Kanai, H. Chem. Lett. 1981, 395. Cis isomer: Inamasu, S.: Horiike, M. Inoue, Y. Bull. Chem. Soc. Jpn. 1969, 42,1393. 